\title{
Drivers of Strategic Approach to Philanthropy in the Czech Republic ${ }^{1}$
}

\author{
Klara Kubickova ${ }^{2}$
}

Submitted: 20.04.2020. Accepted: 14.07.2021

\section{Abstract}

Purpose: This study aims to provide an empirical study of the factors that influence how companies engage in strategic philanthropy and philanthropic strategy.

Methodology: A target group of Czech companies engaged in corporate philanthropy was contacted with an e-mail containing a hyperlink to an online questionnaire. In total, 296 companies participated in the study. Secondary data was collected from the Albertina database, Anopress IT database, and 2016-2018 annual reports. Logistic regression and likelihood-ratio tests were used to analyze the data.

Findings: The results imply that company size, ownership, industry, slack resources, and visibility are predictors of philanthropic strategy. Company size and headquarters' location are predictors of strategic philanthropy. The legitimacy strategy and slack resource theory may explain engagement in philanthropic strategy, but not in strategic philanthropy.

Originality: This study contributes to scarce research addressing the drivers of the strategic approach to philanthropy. It provides a comprehensive empirical study of the factors influencing strategic philanthropic practices in the Czech Republic.

Keywords: strategic philanthropy, philanthropic strategy, corporate philanthropy, Czech Republic.

JEL: M14

\footnotetext{
1 This study was supported by the Internal Grant Agency (IGA) of the University of Economics, Prague under Grant F3/54/2018 Strategic Philanthropy: The Comparison of Approaches to Measuring the Impact of Philanthropic Activities of Private Companies and Non-Profit Organizations.

2 Prague University of Economics and Business, W. Churchill Sq. 1938/4 130 67, Prague 3, Czech Republic; klara.kubickova@vse.cz, https://orcid.org/0000-0001-6677-7603.
} 


\section{Introduction}

Over the past several years, the strategic role of corporate philanthropy has been indicated by academics and practitioners alike (Porter and Kramer, 2006; Wójcik, 2016; Wójcik, 2018). The main proposition of the strategic approach to philanthropy is that acts of corporate philanthropy that benefit society also strategically benefit the very business engaged in such acts (Wójcik, 2018). The different strategic motives behind the corporate philanthropic activities include enhanced corporate reputation, employee and customer commitment, and partnership opportunities (Post and Waddock, 1995; Brammer and Millington 2005; Chojnacka and Wiśniewska, 2016).

To verify strategic philanthropic behavior in practice, researchers test the relationship between charitable contributions and the factors that represent strategic motive (Gan, 2006; Amato and Amato, 2012). However, the existing research focuses primarily on finding the factors affecting the amount of philanthropic expenditure. This empirical study analyzes the influence of factors identified in the corporate philanthropy literature on defined proxy measures of strategic approach to philanthropy. It aims to contribute to a better understanding of:

- specifics of strategic philanthropy practices in the Czech Republic,

- differences between strategic philanthropy and philanthropic strategy,

- and the strategic motivations for corporate philanthropy.

This study examines strategic approach to philanthropy in the Czech Republic. Philanthropic donations in post-communist countries may differ from those in the developed capitalist countries where most previous studies were conducted. These differences are often explained by unfavorable economic conditions, the lack of tradition of corporate philanthropy (Anheier and Winder, 2007; Hanousek, Kočenda, and Svítková, 2010), lack of awareness (Adamska, Dabrowski, and Grygiel-Tomaszewska, 2016), and legal framework (Hanousek et al., 2010; Válová and Formánková, 2014). These conditions can affect the development and implementation of new strategies in corporate philanthropy.

In the Czech Republic, Hanousek et al. (2010) analyze the influence of the tax policy, company size, ownership structure, industry, and geographical level of operation on the amount spent on philanthropic contributions. They show that some factors affect corporate philanthropy in the Czech Republic differently than in other countries. The studies analyzing the drivers of strategic philanthropic approach are represented by Maas and Liket (2011) and Liket and Maas (2016). These authors analyze the influence 
of company size, industry, region, philanthropic expenditure, and profit in companies ranked in the Dow Jones Sustainability Index (DJSI). This study analyzes how factors identified by these authors affect strategic approach to corporate philanthropy in the Czech Republic. Furthermore, it analyzes the influence of other factors highlighted in corporate philanthropy literature: slack resources, ownership, and visibility. This study also separates the different strategic approaches to corporate philanthropy, as designed by Post and Waddock (1995).

First, I will explain the proxy measures of a strategic approach to philanthropy and discuss the drivers of corporate philanthropy from the perspective of this strategic approach. Second, the text will outline the data collection and statistical procedures used. The study uses primary data from a questionnaire survey among corporate donors and secondary data about these donors. Third, I will present the results of the analysis. The study will conclude with a discussion of the results and their implications for further research. This study shows that the Czech companies engaged in corporate philanthropy participating in this study are at the beginning of the implementation of strategic processes associated with corporate philanthropy. In general, it provides a new perspective on the research of strategic behavior in philanthropy by applying the existing approaches within the corporate philanthropy literature to two different models of strategic philanthropic approach.

\section{Theoretical Background and Hypotheses Development}

\section{Main Assumptions of Applied Theories}

Whether companies should engage in philanthropy for charitable or selfish reasons is a point of long-standing discussion. From the perspective of stakeholder theory, responsibility to engage in corporate philanthropy is framed in moral and ethical terms (Sundaram and Inkpen, 2004; Keay, 2007). According to slack resource theory, companies engage in corporate philanthropy when available resources allow it (Amato and Amato, 2012). Under the shareholder and agency theory, managers make decisions that maximize shareholder value (Sundaram and Inkpen, 2004). This view does not prevent engaging in corporate philanthropy. However, it only accepts philanthropic activities that have a positive impact on the bottom line (Godfrey, 2005; Wójcik, 2016; Wójcik, 2018). This positive impact can be achieved either directly or indirectly by philanthropy that enhances corporate reputation (Brammer and Millington 2005; Chojnacka and Wiśniewska, 2016), employee and customer commitment (Block, Glavas, Mannor, and Erskine, 2017), or legitimacy (Chen and Roberts, 2010; Wójcik, 2018). Legitimacy theory focuses on strategies that organizations can use to ensure their 
long-term survival through pursuing socially acceptable goals (Chen and Roberts, 2010; Wójcik, 2018). The philanthropy with a positive impact on the bottom line is called strategic philanthropy. It offers a compromise to the proponents and opponents of corporate philanthropy (Buchholtz, Amason, and Rutherford, 1999; Seifert, Morris, and Bartkus, 2003). According to the existing descriptive literature (Post and Waddock, 1995; Porter and Kramer, 2006), many companies are shifting away from altruistic discretionary charitable giving and adopt a more strategic, bottom-line oriented approach to philanthropy.

Despite the descriptive literature and the theoretical perspectives that highlight the strategic rationale behind corporate philanthropy, researchers have not focused on testing the hypotheses that are supposed to drive strategic corporate giving. The studies analyzing the drivers of strategic philanthropy are represented by Maas and Liket (2011) and Liket and Maas (2016). Factors that were found to influence whether DJSI companies practice strategic philanthropy are company size, industry, region, and the level of philanthropic expenditures. Corporate philanthropy literature further highlights the influence of slack resources (Buchholtz et al., 1999; Amato and Amato, 2012), ownership (Buchholtz et al., 1999; Hanousek et al., 2010; Wang and Qian, 2011), company's headquarters (Hanousek et al., 2010; Marquis and Lee, 2013), and visibility (Gan, 2006; Wang and Qian, 2011). The influence of these factors on strategic approach to corporate philanthropy has not been tested. Moreover, different strategic approaches as designed by Post and Waddock (1995) have not been compared.

\section{Strategic Approach to Philanthropy}

If a company makes strategically focused philanthropic contributions, its social and economic objectives can no longer be considered separately. Such philanthropy has the dual purpose of benefiting both the social welfare and the bottom line of the business (Saiia Carroll, and Buchholtz, 2003; Porter and Kramer, 2006; Maas and Liket, 2011; Liket and Maas, 2016). In other words, strategic philanthropy is professionalism in the giving function, in which companies consider philanthropy as any other business activity (Saiia et al., 2003; Maas and Liket, 2011). This activity is designed to deliver measurable benefits over a given period (Porter and Kramer, 2006; Maas and Liket, 2011; Liket and Maas, 2016). Therefore, corporate philanthropic contributions are linked not only to the needs of the community but also to strategic plans and objectives (Hess, Rogovsky, and Dunfee (2002).

However, Post and Waddock (1995) distinguished strategic philanthropy from philanthropic strategy. Philanthropic strategy means that a company has clear goals for its 
philanthropic program and a strategy for achieving those goals. Strategic philanthropy is a broader concept that considers the overall strategic focus of the company. It attempts to use philanthropic programs as a tool through which company business goals can be realized. Although managers may adopt a strategic approach to managing corporate philanthropy, their effort remains philanthropic strategy until they integrated philanthropy into a company's overall business orientation, thereby transform it into strategic philanthropy (Saiia et al., 2003). Table 1 shows the main features of strategic philanthropy and philanthropic strategy.

Table 1. Main features of strategic approaches to corporate philanthropy

\section{Strategic philanthropy}

The impact of charitable resources on both

Focus business and society (Saiia et al., 2003; Porter and Kramer, 2006; Maas and Liket, 2011; Liket and Maas, 2016)

\begin{tabular}{l|l}
$\begin{array}{l}\text { Proxy } \\
\text { measure }\end{array}$ & $\begin{array}{l}\text { The measurement of impact } \\
\text { and business }\end{array}$ \\
\hline
\end{tabular}

Scholars argue that the measurement of impact of philanthropic activities on society and business represents a vital proof that company is striving for the social and financial benefits.

Clarification Measuring the impact of philanthropic activities, which is crucial to strategic decision-making, is a key indicator that a company is pursuing the strategic approach (Maas and Liket, 2011; Liket and Maas, 2016).

\section{Philanthropic strategy}

The donation system (Post and Waddock, 1995; Hess et al. (2002; Saiia et al., 2003; Campbell and Slack, 2008)

The presence of a strategic plan for philanthropic activities

Hess et al. (2002) state that the shift to strategic management of corporate philanthropy has prompted the need to set goals for this area. Setting specific goals in a strategic plan for philanthropic activities is an important first step for the strategic management of corporate philanthropy (Post and Waddock, 1995; Heike Bruch, 2005).

Source: own elaboration.

\section{Drivers of Corporate Philanthropy from the Perspective of Strategic Approach}

Theoretical arguments and previous empirical research suggest that different corporate and market characteristics influence corporate philanthropy (Gautier and Pache, 2015). This article builds a framework for exploring the influence of these characteristics upon strategic approaches to philanthropy. 


\section{Company Size}

Large companies donate more, regardless of their profitability (Buchholtz et al., 1999; Seifert et al., 2003; Brammer and Millington, 2006; Brammer and Millington, 2008; Amato and Amato, 2012). The reason is greater access to resources (Buchholtz et al., 1999; Brammer and Millington, 2006; 2008) and greater visibility (Brammer and Millington, 2006; 2008; Marquis and Lee, 2013). The rationale behind the relationship between the strategic approach to philanthropy and company size is based on a more advanced administrative architecture and processes in large companies. This architecture improves the company's ability to respond to societal challenges (Valor, 2006; Brammer and Millington, 2006). Large companies are more often approached by nonprofit organizations with a request for a financial contribution. To reduce transaction costs, large companies create standardized procedures for processing these requests. They also run more formalized programs and allocate resources among non-profit beneficiaries more consistently (Useem, 1988; Válová and Formánková, 2014). This indicates the presence of a strategic plan for philanthropic activities in larger companies. Large companies are also more willing to use sophisticated accounting methods and collect information from the surrounding market (Mohan-Neill, 1995; Maas and Liket, 2011). Together with more developed administrative processes, higher availability of financial, and human resources, these are the basic preconditions for impact measurement practices (Barraket and Yousefpour, 2013). Thus, I hypothesize that:

H1a: There is a positive relationship between company size and philanthropic strategy.

H1b: There is a positive relationship between company size and strategic philanthropy.

\section{Profitability and Slack Resources}

It is widely accepted that philanthropic contributions depend on profitability (Buchholtz et al., 1999; Seifert et al., 2003; Amato and Amato, 2012). Companies donate to reduce taxable income and use a fixed percentage of pre-tax profits to decide how much they donate. However, the empirical findings are inconclusive (Buchholtz et al., 1999; Brammer and Millington, 2006; 2008; Amato and Amato 2012). The problem of finding a consistent relationship between financial and social performance is a function of the variety of measures used for both financial and social performance (Buchholtz et al., 1999). Moreover, accounting instruments do not show whether a company has already absorbed its profits, thereby making them unavailable for further use. Therefore, corporate philanthropy is likely to be related to corporate slack resources (Buchholtz et al., 1999; Amato and Amato, 2012). It is a common assumption in corporate 
social responsibility literature that if discretionary funds are available, a certain percentage should be provided for charitable purposes (Seifert et al., 2003). Slack resource theory indicates a positive relationship between corporate charitable contributions and profitability (Brammer and Millington, 2006). However, different forms of corporate philanthropy are logically not related to slack resources or profitability in the same way (Seifert et al., 2003). Philanthropic strategy requires the availability of information regarding how much funding will be available in a certain time frame for discretionary activities. Strategic philanthropy, on the other hand, is not a discretionary activity but is like any other business activity. Liket and Maas (2016) confirmed this empirically when they found that, despite their expectations, earnings before interests and taxes do not affect a company's engagement in strategic philanthropy. Thus, I hypothesize that:

H2a: There is a positive relationship between a company's profitability and philanthropic strategy.

H2b: There is no relationship between a company's profitability and strategic philanthropy.

H3a: There is a positive relationship between a company's slack resources and philanthropic strategy.

H3b: There is no relationship between a company's slack resources and strategic philanthropy.

\section{Industry}

As demonstrated in several empirical studies, corporate philanthropy varies across industries (Brammer and Millington, 2006; 2008; Hanousek et al., 2010; Amato and Amato, 2012). Companies in industries that are highly dependent on public perception or that have greater public exposure tend to give more (Brammer and Millington, 2005; 2008; Gan, 2006, Amato and Amato, 2012). For many companies, philanthropic activities are part of a PR strategy and play an important role in stakeholder management. Effective philanthropic strategy can lead to a more positive perception of the business by stakeholders and can help mitigate the impact of negative externalities (Brammer and Millington, 2004; 2005; 2006; Gan, 2006; Amato and Amato, 2012). This indicates differences in the presence of philanthropic strategy across industries. The hypothesis regarding strategic philanthropy is possible to derive from the practice of non-financial reporting. Reporting of non-financial information is often linked to impact measurement (Costa and Pesci, 2016; Liket and Maas, 2016). Available data (Blasco and King, 
2017) confirms the differences in non-financial reporting between industries in the Czech Republic. Industries with high environmental and social impacts, such as the oil, gas, and mining industries, usually have higher reporting rates. Similarly, available studies (Maas and Liket, 2011; Liket and Maas, 2016) have found that there are differences in the impact measurement practices in different industries. Thus, I hypothesize that:

H4a: Philanthropic strategy varies depending on the industries in which companies operate.

H4b: Strategic philanthropy varies depending on the industries in which companies operate.

\section{Visibility}

Public interest in corporate activities can put pressure on companies to focus more on social issues (Brammer and Millington, 2006). Companies that are more visible are subjected to greater scrutiny. If mismanaged, this scrutiny can lead to higher costs in terms of lost competitive advantages, increased taxation, regulation, and even litigation (Gan, 2006). Corporate philanthropy can play a key role in cultivating a positive, socially responsible image for a company (Saiia et al., 2003; Brammer and Millington, 2005; Chojnacka and Wiśniewska, 2016). Furthermore, companies perceived as beneficial to society are considered legitimate and can continue their operations (Chen and Roberts, 2010). Visibility can also increase the benefits a company gains from corporate philanthropy (Wang and Qian, 2011). Corporate philanthropy can be beneficial to shareholders because it improves the position of a company. It also benefits the public through the good that companies do in response to public pressure (Gan, 2006). Therefore, visibility can generate greater benefits and drive strategic approaches to philanthropy. Saiia et al. (2003) found that a higher level of company exposure relates to a higher level of strategic philanthropy. Thus, I hypothesize that:

H5a: A company's visibility is positively associated with philanthropic strategy.

H5b: A company's visibility is positively associated with strategic philanthropy.

\section{Ownership}

Defined through the level of foreign capital invested in a company, ownership is an important factor of corporate philanthropy in the Czech Republic (Hanousek et al., 2010). Post-communist countries were characterized by the inflow of foreign direct investments, one of the basic criteria of successful economic transformation (Hlavacek and Bal-Domanska, 2016). Most foreign direct investment flow in the Czech Republic 
from the Western European countries: the Netherlands, Germany, Austria, France, and Switzerland (KPMG, 2017). Corporate philanthropy began to develop in the Czech Republic after the termination of the centrally planned economy. On the other hand, in Western European countries, philanthropy has a long tradition (Hanousek et al., 2010). This long tradition can positively affect the implementation of philanthropic strategies. Brammer, Millington, and Pavelin (2006) found that $84 \%$ of a sample of companies traded on the London Stock Exchange had formulated a plan for managing philanthropic contributions. The non-financial information reporting rates of Western European countries - from which foreign direct investments flow to the Czech Republic - are also much higher (Blasco and King, 2017) On the contrary, the level of non-financial information reporting in the Czech Republic is lower than the global average. Since foreign owners often transfer their domestic corporate practices, know-how, and management methods from the parent company (Hlavacek and Bal-Domanska, 2016), foreign-owned companies in the Czech Republic are more likely to be engaged in the strategic philanthropic approaches. Thus, I hypothesize that:

H6b: Foreign-owned companies are more likely to have implemented a philanthropic strategy.

H6a: Foreign-owned companies are more likely to be engaged in strategic philanthropy.

\section{Headquarters' Location}

Previous research suggests that corporate location is an important determinant of corporate philanthropy (Marquis and Lee, 2013). Moreover, companies provide more resources in areas where the demand for resources is higher (Useem, 1988; Hanousek et al., 2010). The greater the number of hospitals, art organizations, educational institutions, and social agencies in the region, the higher the rate of corporate donations. Hanousek et al. (2010) observe that companies in the Czech capital of Prague donate more compared to companies located in other regions. The more a company spends on philanthropy, the more its philanthropic programs become professional and strategic (Useem, 1988). Empirical studies also show that the location of the company influences the involvement in impact measurement (Maas and Liket 2011; Liket and Maas, 2016). Thus, I hypothesize that:

H7a: There is a positive relationship between the location of a company's headquarters in a capital city and philanthropic strategy. 
H7b: There is a positive relationship between the location of a company's headquarters in a capital city and strategic philanthropy.

\section{Philanthropic Expenditures}

Philanthropic expenditures appear in corporate philanthropy studies as a dependent variable, either as an absolute amount (Buchholtz et al., 1999; Seifert et al., 2003; Gan, 2006; Wang and Qian, 2011; Marquis and Lee, 2013) or as a ratio of total revenue (Amato and Amato, 2012) and profits (Maas and Liket, 2011; Liket and Maas, 2016). Higher philanthropic expenditures increase the relative visibility of the company, leading to increased stakeholder attention (Useem, 1988; Maas and Liket, 2011). As a result, decision-making in corporate philanthropy programs should incorporate consistent internal structures, budget levels, and resource allocation policies (Useem, 1988). As already mentioned, the more a company spends on philanthropy, the more its philanthropic programs become professional and strategic. Relatively higher philanthropic expenditures are also usually accompanied by more ambitious goals. Therefore, measuring whether these goals are achieved becomes more important (Maas and Liket, 2011; Liket and Maas, 2016). Few studies use the amount of philanthropic expenditure as an independent variable (Maas and Liket, 2011; Liket and Maas, 2016), yet they confirm a positive relationship with the impact measurement. Thus, I hypothesize that:

H8a: There is a positive relationship between the level of philanthropic expenditures and philanthropic strategy.

H8b: There is a positive relationship between the level of philanthropic expenditures and strategic philanthropy.

\section{Research Method}

\section{Research Design}

To explore the drivers of strategic approach to philanthropy a framework was constructed including three dependent and eight independent variables. Combining each of the dependent variables with all independent variables in a regression analysis showed the relative importance of each of the individual predictors. The conceptual framework is shown in Figure 1. 


\section{Figure 1. Conceptual Framework}

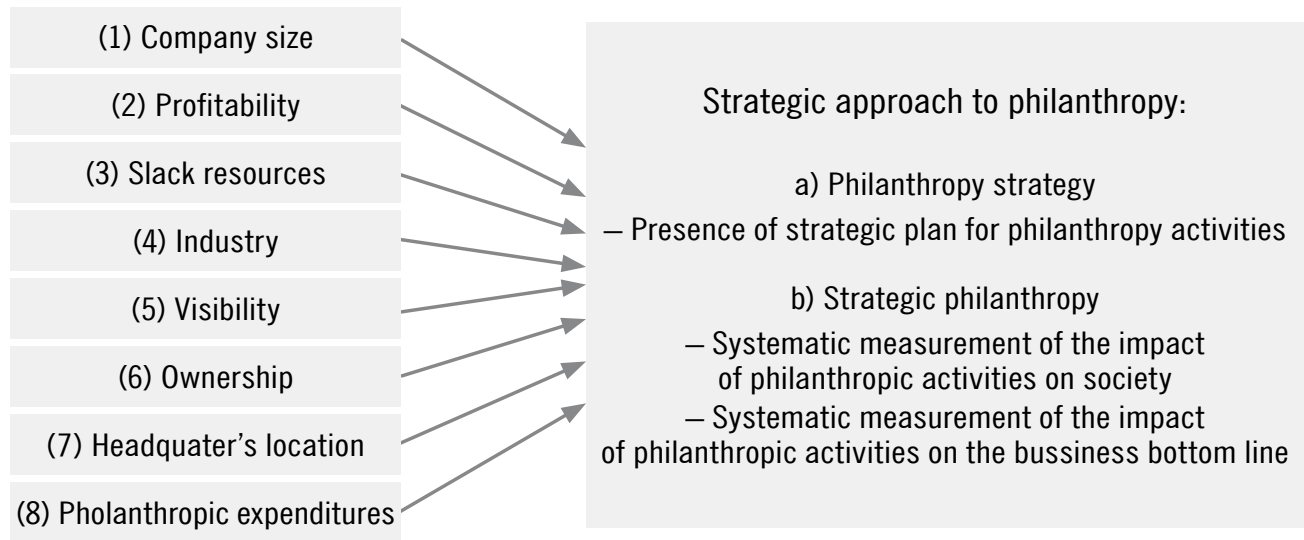

Source: own elaboration.

\section{Data Collection}

The target group consisted of companies that meet the following criteria:

- legal entities registered in the Czech Republic,

- companies engaged in corporate philanthropy,

- corporate philanthropic contributions made through direct support or through a corporate foundation (corporate resources),

- corporate philanthropic contributions provided to non-profit organizations, which informs about the received support in its annual report.

In total, the target group included 4026 company donors listed in the annual reports of non-profit organizations registered in the catalog of Czech non-profit organizations. The Albertina database provided further information about companies, including e-mail addresses. The target group was contacted with an e-mail containing a hyperlink to the online survey. In total, 296 companies participated in the study (response rate of $7.4 \%$ ). Secondary data was collected using the Albertina database, Anopress IT, and annual reports from 2016-2018.

\section{Research Variables}

The dependent variable of philanthropic strategy was defined by the presence of a strategic plan for philanthropic activities in the company (1) (YES/NO). The dependent variable of strategic philanthropy was defined through the systematic measurement 
of the impact of philanthropic activities on society (2) (YES/NO) and on the business bottom line (3) (YES/NO).

The traditional indicators of company size included the size of assets (Brammer and Millington, 2006; 2008), sales (Buchholtz et al., 1999; Hanousek et al., 2010), market capitalization (Maas and Liket, 2011; Liket and Maas, 2016), and the number of employees (Hanousek et al., 2010). This study used the European Commission's definition of small and medium-sized enterprises (European Commission, 2015). The categories were (a) micro ( $<10$ employees, annual turnover $\leq 2$ million EUR/annual balance sheet total $\leq 2$ million EUR); (b) small $(<50$ employees, annual turnover $\leq 10$ million EUR/ annual, balance sheet total $\leq 10$ million EUR); (c) medium-size $(<250$ employees, annual turnover $\leq 50$ million EUR/annual balance sheet total $\leq 43$ million EUR), and (d) large. Profitability was measured as the return on sales (ROS) (Buchholtz et al., 1999), while slack resources as net profit after taxes plus depreciation minus capital expenditure (Buchholtz et al., 1999; Seifert et al., 2003). The industry was classified according to CZ-NACE as assigned through the Albertina database. The CZ-NACE categories were logically grouped into nine categories: trade; manufacturing; information and communication; finance; professional, scientific, and technical activities; construction; health and social care; culture and recreation; and others. Regarding visibility, Gan (2006) states that this variable cannot be measured directly, so the challenge is to select the appropriate proxy measure. Empirical studies often look to a company's size (Brammer and Millington, 2008) or advertising expenditures (Wang and Qian, 2011). Based on Brammer and Millington (2005; 2006) and Gan (2006), corporate visibility was measured with the number of occurrences of the company name in the media. This number was determined by using Anopress IT. Ownership was classified according to investor nationality. The categories were (a) Czech investor (90-100\% of Czech capital); (b) predominantly Czech investor (50-90\% of Czech capital); (c) predominantly foreign investor (50-90\% of foreign capital); (d) foreign investor (90-100\% of foreign capital) (Donors Forum, 2004). Variable headquarters' location had two values: YES, if the company is headquartered in Prague; and NO, if it is headquartered in other regions. The level of philanthropic expenditures was calculated as the natural logarithm of philanthropic expenditures reported in the questionnaire survey (Buchholtz et al., 1999; Seifert et al., 2003; Gan, 2006; Marquis and Lee, 2013).

\section{Statistical Procedure}

The dichotomous nature of the dependent variables was ideal for logistic regression. Logistic regression provides an estimate coefficient indicating the probability that the dependent variable will change based on the knowledge of the independent variables. 
It also provides odds ratios (Exp B). For the categorical variables, the category with the largest share of observations served as the reference category. Furthermore, likelihood-ratio tests between the unrestricted model (all independent variables included) and the restricted model (all but the variable in question included) were used to verify the logistic regression results. Since company characteristics can change over time, the analysis covered three years 2016-2018, as suggested by Buchholtz et al. (1999) and Maas and Liket (2011).

\section{Data Analysis and Results}

Table 2 displays the characteristics of the sample of Czech companies engaged in corporate philanthropy. The sample included mostly small companies (32.4\%), companies with a Czech investor (72.8\%), and companies located outside the capital $(55,9 \%)$. Trade companies (19.6\%), companies focused on professional, scientific, and technical activities (18.9\%), and manufacturers (15.9\%) were the most represented in the sample in terms of industry. A strategic plan for philanthropic activities appeared among 34.1\% of the surveyed companies. Only $24 \%$ of companies measured the impact of such activities. Among the studied companies, $16.9 \%$ measured the impact of their philanthropy on society, while $11.8 \%$ measured business impacts. Only $4.7 \%$ of companies measured both categories of impact simultaneously. The results indicated that the probability of having a strategic plan for philanthropy increases with company size. The presence of a strategic plan also prevailed in companies with predominantly Czech investors (77.8\%), those that operated in the financial sector (60.9\%), and were headquartered in the capital (42.3\%). The descriptive statistics further implied that medium-sized companies and companies headquartered outside the capital measured the impact of their philanthropy on society relatively less often. The results were reported in percentages relative to the frequencies in each category and were consistent over the surveyed years.

Table 2. Overview of descriptive statistics: categorical variables (\%), $\mathrm{N}=296$

\begin{tabular}{|l|c|c|c|c|}
\hline & $\mathbf{( 1 )}$ & $\mathbf{( 2 )}$ & $\mathbf{( 3 )}$ & Total \\
\hline Total & 34.1 & 16.9 & 11.8 & $100.0 \%$ \\
\hline & \multicolumn{2}{|c|}{ Company size } & & \\
\hline Micro & 16.9 & 28.2 & 14.1 & 24.0 \\
\hline Small & 29.2 & 14.6 & 11.5 & 32.4 \\
\hline Medium-sized & 36.8 & 4.4 & 7.4 & 23.0 \\
\hline
\end{tabular}




\begin{tabular}{|c|c|c|c|c|}
\hline Large & 59.0 & 21.3 & 14.8 & 20.6 \\
\hline \multicolumn{5}{|c|}{ Ownership } \\
\hline Czech investor & 31.2 & 17.7 & 13.0 & 72.6 \\
\hline Predominantly Czech investor & 77.8 & 33.3 & 11.1 & 3.0 \\
\hline Predominantly foreign investor & 26.0 & 12.0 & 12.0 & 16.9 \\
\hline Foreign investor & 54.5 & 13.6 & 0.0 & 7.4 \\
\hline \multicolumn{5}{|c|}{ Industry } \\
\hline Trade & 27.6 & 15.5 & 10.3 & 19.6 \\
\hline Manufacturing & 21.3 & 17.0 & 8.5 & 15.9 \\
\hline $\begin{array}{l}\text { Information and } \\
\text { communication activities }\end{array}$ & 48.0 & 8.0 & 12.0 & 8.4 \\
\hline Finance & 60.9 & 13.0 & 17.4 & 7.8 \\
\hline $\begin{array}{l}\text { Professional, scientific, and } \\
\text { technical activities }\end{array}$ & 23.2 & 23.2 & 12.5 & 18.9 \\
\hline Construction & 29.6 & 7.4 & 7.4 & 9.1 \\
\hline Health and social care & 50.0 & 15.0 & 5.0 & 6.8 \\
\hline Culture, recreation & 41.2 & 23.5 & 11.8 & 5.7 \\
\hline Others & 47.8 & 26.1 & 26.1 & 7.8 \\
\hline \multicolumn{5}{|c|}{ Headquarters' location } \\
\hline In the capital & 42.3 & 25.2 & 15.4 & 44.1 \\
\hline Outside the capital & 26.9 & 10.9 & 10.3 & 55.9 \\
\hline
\end{tabular}

Note: (1) Presence of strategic plan for philanthropic activities (YES), (2) Impact on society measurement (YES), (3) Impact on business measurement (YES).

Headquarters' location: $\mathrm{N}=279$ (17 missing cases).

Source: own elaboration.

Table 3 presents the summary statistics of continuous variables. The table shows that the average philanthropic contribution varied from 4.941 to 5.010 as measured by the natural logarithm of reported philanthropic contributions for each year. The mean value of slack resources varied from 9223372 to 708956016 CZK. The table shows a mean ROS from 7.3\% to 8.3\%. Measured in terms of occurrences of the company name in the media, visibility varied from 0 to 14 518, with a mean ranging from 196.510 to 211.020 . 
Table 3. Overview of descriptive statistics: continuous variables

\begin{tabular}{|l|c|c|c|c|c|}
\hline & N & Minimum & Maximum & Mean & Std. Deviation \\
\hline Fil. expenditures 16 & 245 & 0.693 & 14.484 & 4.941 & 2.125 \\
\hline Fil. expenditures 17 & 249 & 0.693 & 12.133 & 4.992 & 1.968 \\
\hline Fil. expenditures 18 & 249 & 0.693 & 12.076 & 5.010 & 1.971 \\
\hline Slack resources 16 & 240 & -11271747.000 & 14982000.000 & 9223.372 & 9223.372 \\
\hline Slack resources 17 & 234 & -5291445.000 & 14895000.000 & 175680.363 & 1584177.561 \\
\hline Slack resources 18 & 162 & -4058256.000 & 30193000.000 & 708965.016 & 3926636.497 \\
\hline R0S16 & 237 & -5.084 & 4.210 & 0.073 & 0.789 \\
\hline R0S17 & 232 & -0.677 & 5.169 & 0.158 & 0.576 \\
\hline R0S18 & 160 & -0.910 & 1.473 & 0.083 & 0.245 \\
\hline Visibility16 & 279 & 0.000 & 14518.000 & 211.020 & 1295.772 \\
\hline Visibility17 & 279 & 0.000 & 13955.000 & 196.510 & 1241.832 \\
\hline Visibility18 & 279 & 0.000 & 12575.000 & 198.050 & 1143.630 \\
\hline
\end{tabular}

Note: Slack resources in thousand CZK.

Source: own elaboration.

The Pearson correlation coefficient between the variables of a strategic plan and social impact measurement (0.018) and strategic plan and business impact measurement $(0.23)$ was not significant at 0.05 . This suggested that there was not a significant relationship between the presence of a strategic plan for philanthropic activities and measuring the goals achieved. The correlation coefficient between the impact measurement practices was 0.226 and was significant at level 0.01 , although the value was not very high. This suggested that each of the independent variables still measures a different type of impact measurement (Maas and Liket, 2011).

Before performing the logistic regression, the assumptions of this technique had to be fulfilled. For the categorical variables, an $\chi^{2}$ test showed the relationship between the dependent and independent variables (Table 4). For the continuous variables, a Mann-Whitney U test was used, as the data did not satisfy the properties of a normal distribution. This was made evident by the Kolmogorov-Smirnov test (Table 5). The factors entering the logistic regressions are displayed in the tables below. In terms of business impact measurement, none of the factors demonstrated a significant dependence in any of the analyzed years. 
Table 4. Relationship between the dependent and categorical independent variables

(1)
(2)

(3)

\begin{tabular}{|l|c|c|c|c|c|c|}
\hline & Pearson $\chi^{\mathbf{2}}$ & Cramer's V & Pearson $\chi^{\mathbf{2}}$ & Cramer's V & Pearson $\chi^{\mathbf{2}}$ & Cramer's V \\
\hline Company size & $27.444^{\star *}$ & .304 & $15.189 *$ & .227 & 2.166 & .086 \\
\hline Ownership & $12.928^{\star}$ & .209 & 2.631 & .098 & 5.831 & .105 \\
\hline Industry & $21.762^{\star}$ & .271 & 7.362 & .154 & 6.482 & .156 \\
\hline $\begin{array}{l}\text { Headquarters' } \\
\text { location }\end{array}$ & $7.257^{\star}$ & .161 & $9.881^{\star}$ & .188 & 1.689 & .078 \\
\hline
\end{tabular}

Notes: (1) Presence of strategic plan for philanthropic activities (YES), (2) Impact on society measurement (YES), (3) Impact on business measurement (YES), ${ }^{*} p<0.05,{ }^{* *} p<0.001$.

Source: own elaboration.

This study also tested collinearity. A variance inflation factor (VIF) greater than 10 indicates a collinearity problem (O'Brien, 2007). The data did not yield critical VIF values (the highest VIF was 2.944).

The results of the logistic regression (Appendix I) showed that micro-companies engaged in corporate philanthropy in the Czech Republic were less likely to have a strategic plan for philanthropic activities than small companies (H1a). This relationship was significant in 2016 and 2017. However, the results did not show that larger companies measure their philanthropic impact more (H1b). It shows that micro-companies measured the impact of their philanthropy on society more frequently than small companies. Slack resources and profitability were significant predictors of having a strategic philanthropic plan. The relationship was significant for slack resources in 2016 and 2017 and for profitability in 2018 (H3a). As expected, profitability and slack resources did not influence engagement in strategic philanthropy in the surveyed companies (H2b, H3b). In different industries, there were differences in engagement in philanthropic strategy (H4a) but not strategic philanthropy (H4b). Companies operating in health and social care were more likely to implement a strategic philanthropic plan in 2016 and 2017, relative to the reference category of trade. Visibility was a significant predictor of a philanthropic strategy in all years (H5a). This did not apply to strategic philanthropy (H5b). The hypothesized relationships regarding variable ownership were not confirmed (H6a and H6b). Companies with predominantly foreign investors were less likely than Czech companies to have a strategic philanthropic plan. For the predictive variable of headquarters' location, the results showed that companies headquartered in Prague were more likely to have 


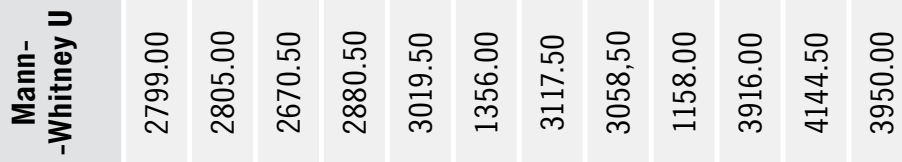

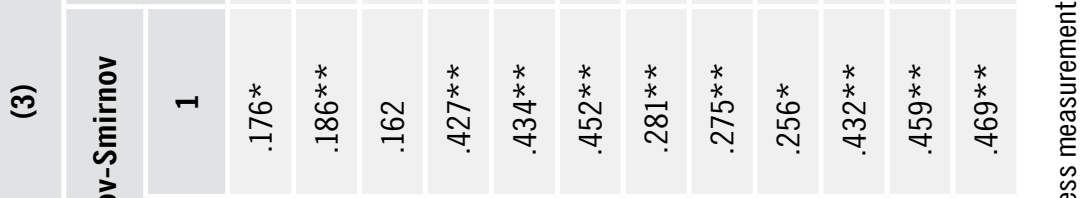

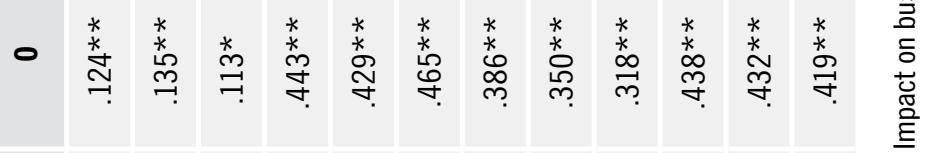

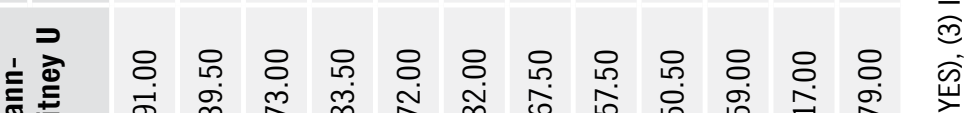

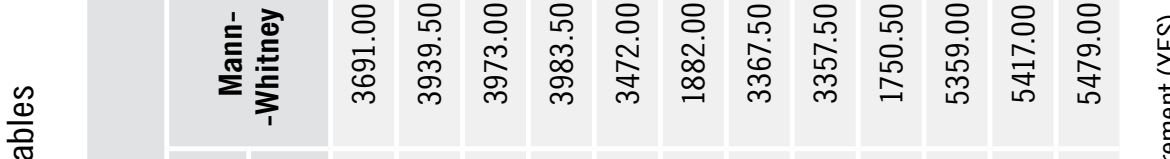

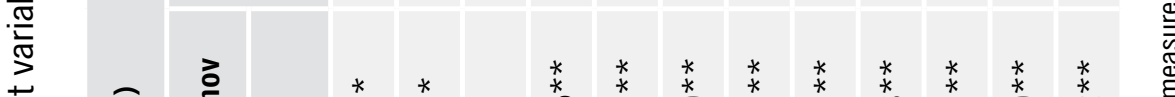

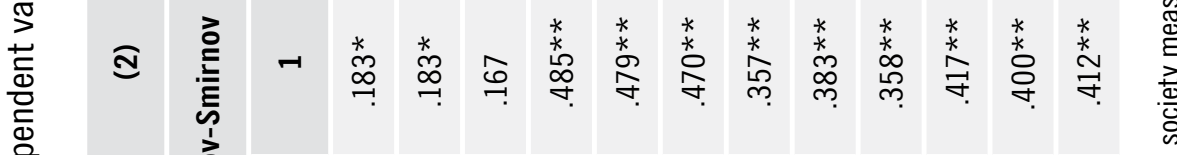

$$
\begin{aligned}
& \text { 을 }
\end{aligned}
$$

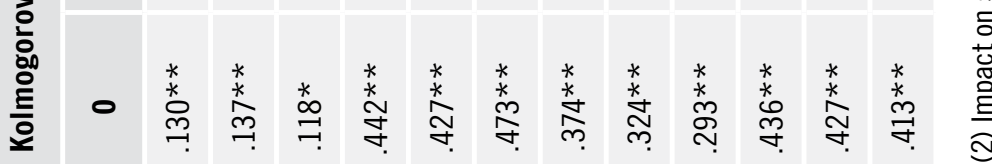

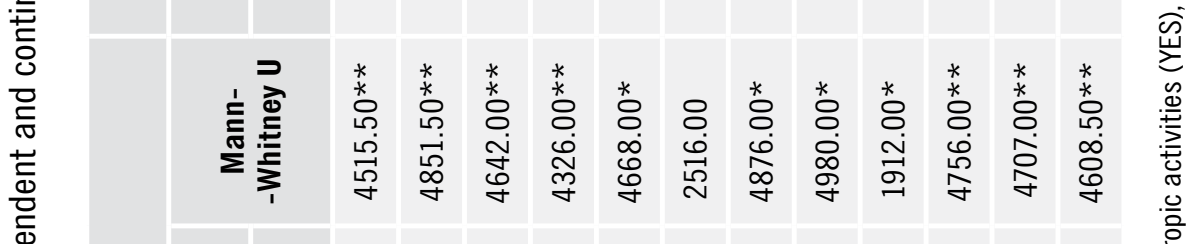

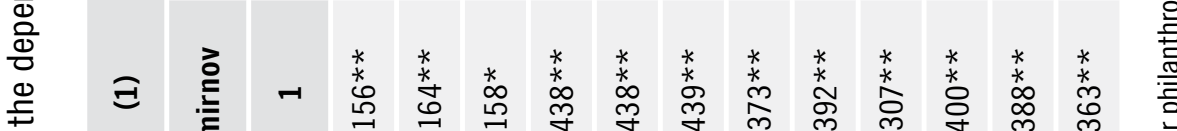

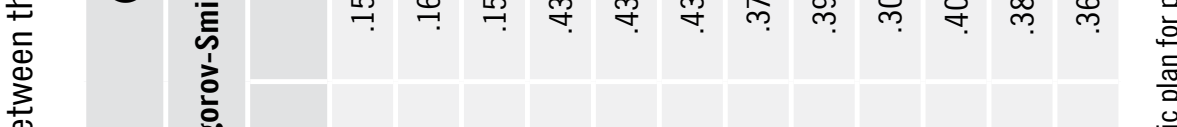

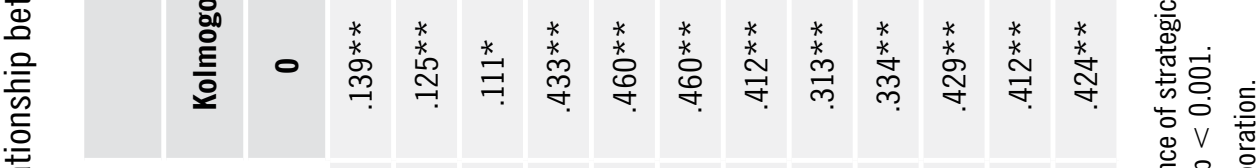

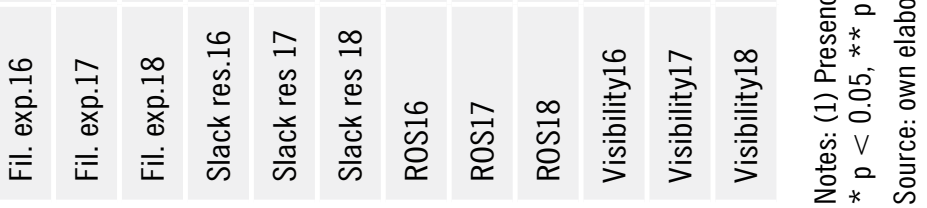$$
\text { 음 }
$$ 
a strategic philanthropic plan than companies in other regions (H7a). However, this relationship was significant only for 2017. Moreover, companies headquartered in Prague measured their impact on society more frequently than companies in other regions (H7b). The results did not confirm that there is a positive relationship between philanthropic expenditures and a strategic approach to philanthropy (H8a and H8b).

A comparison of the restricted and unrestricted models with a likelihood-ratio test further verified the findings (Table 6). The test's results imply that company size, ownership, industry, slack resources, and visibility were predictors of having a strategic philanthropic plan in both 2016 and 2017. Furthermore, the headquarters' location was found to be a significant predictor in 2017. The results also confirmed that ownership, profitability, and visibility were significant predictors in 2018. Finally, both the company size and headquarters' location were significant predictors of social impact measurement in all three years.

Table 6. Results of likelihood ratio tests

(1)

\section{6}

$52.169 * *$

$29.797 * *$

22.876 *

2.471

2.475

$16.614^{* *}$

1.738

$23.168^{* *}$

2.120

\section{7}

12.270 *

$27.454^{* *}$

22.244*

$7.025^{*}$

6.611*

Profitability (ROS)

Visibility
0.419

$17.502^{* *}$
(2)

2018

3.572

16.606 *

22.613 **

8.266

.326

9.309*

.923

$6.508 *$

11.180 *

Notes: (1) Presence of strategic plan for philanthropic activities (YES), (2) Impact on society measurement (YES), (3) Impact on business measurement (YES) * $p<0.05$, ** $p<0.001$.

Source: own elaboration.

\section{Discussion}

Corporate philanthropy is developing dynamically in the Czech Republic (Kolibová, 2016). The Czech companies recognize that they should be actively involved in favor of the society in which they operate (Briš and Brišová, 2013). However, in general, like 
in Western European countries, if companies want to be competitive in the era of new economy, they must reflect the advantage of new strategic tools in corporate philanthropic behavior (Kolibová, 2016). Although foreign studies (Marx, 1999; Liket and Maas, 2016) show that strategic approach to philanthropy is implemented at a high level in Western capitalist countries, this is not the case in the Czech Republic. This corresponds with previous Czech studies (Frič, 2001; Donors' Forum, 2004; Štastná et al., 2011). Frič (2001) found that Czech corporate donors most often choose a passive, reactive selection of recipients. Impact measurement is also not widespread in the Czech Republic (Štastná, Fraňková, and Stránský, 2011). The reason may be the lack of standardized methods for impact measurement, the lack of trained professionals promoting international standards of social reporting (Štastná et al., 2011; Adamska et al., 2016), and low willingness to consider non-financial criteria in investment decisions, similar to most post-communist countries (Adamska et al., 2016). This may be due to the short history of Czech corporate donations, one of the consequences of the Czech Republic's communist history (Hanousek et al., 2010).

This study supports Campbell and Slack's (2008) assertion that philanthropic strategy is more common in surveyed companies compared to strategic philanthropy. The analysis also shows differences in the drivers of both concepts. These drivers represent different strategic motives of corporate philanthropy.

In line with Frič (2001) and Donors' Forum (2004), this study shows that corporate philanthropic strategies have been developed mainly by large companies. According to Donors' Forum (2004), these strategies are often not long-term or comprehensive. With few exceptions, small and regional companies do not have a philanthropic strategy. According to Válová and Formánková (2014) and Anheier and Winder (2007), large companies in the Czech Republic usually focus on a long-term partnership with a certain NGO. This fact further certifies the statement that large companies usually have a specific form of philanthropic strategy. A positive relationship between company size and philanthropic strategy implies the legitimacy strategy motive (Chen and Roberts, 2010).

Company size is also a significant predictor of social impact measurement. By leading to the implementation of tools developed for impact measurement, the professionalization of social activities (Liket and Maas, 2016) may play a key role here. According to my assumptions, measurement tools should be developed in larger companies. However, the results show that micro-companies measured the impact of their philanthropy on society more frequently than small companies. Amato and Amato (2012) found that while large companies can use donations to gain legitimacy, smaller com- 
panies can use them to build customer relationships within their community. This conclusion holds for the results found in this study as micro companies can use the results of impact measurement for effective stakeholder management and for building relationships with customers.

Many authors (Buchholtz et al., 1999; Seifert et al., 2003; Amato and Amato, 2012) use profitability and slack resource theory to explain the amounts of philanthropic expenditures companies make. In line with Liket and Maas (2016), the results confirm that profitability and slack resource theory do not appropriately explain a company's engagement in strategic philanthropy. However, these theories may explain engagement in philanthropic strategy. This supports the premise that - unlike corporate philanthropy - strategic philanthropy is not a discretionary activity.

The surveyed companies operating in health and social care were more likely than trade companies to implement a strategic philanthropic plan in 2016 and 2017. However, this finding does not prove the legitimacy of a strategy motive, as confirmed by Liket and Maas (2016). They found that companies operating in "dirty" industries had a higher likelihood of engaging in strategic philanthropy. The motive of companies in health and social care may be to generate as much social benefit as possible by effectively managing contributions according to a certain plan. However, without measuring and evaluating the impact of contributions, which is crucial to strategic decision-making, a strategic plan cannot ensure that contributions yield their highest possible impact.

The positive relationship between visibility and philanthropic strategy implies that more visible companies emphasize the need for a strategic plan for philanthropic activities. Visible companies need to distribute philanthropic contributions in a consistent way that is comprehensible to the public. However, Czech companies engaged in corporate philanthropy do not perceive the information generated by impact measurement as means for communication with the stakeholders as impact measurement literature suggests (Costa and Pesci, 2016). The reason may be that contributing to social issues is not perceived as a competitive advantage in the Czech Republic (Válová and Formánková, 2014). In this case, the evaluation and communication of its impact may not be considered effective.

In surveyed companies with predominantly foreign investors, a strategic plan for philanthropic activities was less likely to be present than it was in Czech companies. Furthermore, the data revealed that ownership was not a significant predictor of impact measuring. The explanation may be that there is often a high concentration of corporate philanthropy close to a company's headquarters (Useem, 1988). It explains that the 
acquisition of one company by another may not affect the practice of corporate philanthropy. This study implies that the location of a company's headquarters in the capital city is a relevant factor for social impact measurement. This may be due to a higher demand for philanthropy in the capital. Furthermore, the higher the expenditures, the more likely companies are to manage them strategically. However, in the Czech Republic, some companies do spend a huge amount on philanthropic contributions without accounting for what becomes of them, or whether the objectives of the contributions are fulfilled.

Contrary to Maas and Liket (2001), the influence of the analyzed factors on business impact measurement was not confirmed. The motives for business impact measurement remain unclear. In addition to market or institutional factors, what deserves the attention of researchers are individual factors such as attitudes of company managers or owners. For example, Buchholtz et al. (1999) found that the greater the managerial discretion and the manager's values in terms of "community service," the more generous the corporate contributions. Buchholtz et al. (1999) claim that strategic philanthropy mitigates the link between the values of a manager and corporate philanthropic behavior. This suggests that there is a need to analyze different individual potential drivers of business impact measurement.

\section{Contribution}

This study contributes to existing research on strategic approaches to philanthropy by providing an empirical study of the factors that influence how companies in the Czech Republic engage in strategic approach to philanthropy. It has several implications for research and practice. First, it applies the existing approaches within the corporate philanthropy literature to two predefined proxy measures of strategic philanthropic behavior, providing a new perspective in the research of strategic behavior in philanthropy. Second, a better understanding of analyzed factors can enhance the development of more effective strategies for corporate philanthropy.

What is especially important is the finding that some categories of companies (e.g. large companies) may have a strategic plan for philanthropic contributions but do not evaluate the impact of these contributions. These companies may recognize the importance of strategic considerations for philanthropy - they may even be endowed with needed capabilities - but still do not implement the full strategic focus. Strategic approach to philanthropy can generate higher benefits not only for the company itself but also for non-profit organizations as recipients of these contributions, the economy, 
and the society (Porter and Kramer, 2006). However, it is especially the impact measurement that can ensure that contributions yield their highest possible impact. From a welfare economic perspective, when companies refrain from measuring impact, scarce company resources could be wasted, providing fewer benefits (Maas and Liket, 2011). This study finds that slack resources, profitability, and visibility can influence the presence of a philanthropic strategy but do not influence whether companies measure the impact of philanthropy. Assuming that companies with more resources and greater visibility can generate higher philanthropic benefits, this finding further emphasizes the argument of the welfare economic perspective. This also applies to surveyed companies operating in health and social care that were more likely to implement a strategic philanthropic plan but, again, without the impact measurement practices. These findings emphasize the need for more empirical evidence of the benefits of strategic approach to philanthropy, for example, related to the ambiguity regarding the link between philanthropy and corporate financial performance (Seifert et al., 2003; Godfrey, 2005). Furthermore, this study emphasizes the need to analyze the reasons why the strategic approach is implemented at different levels not only in different categories of companies but also in different countries. Very little is known about the strategic potential of socially responsible practices in post-communist countries (Anheier and Winder, 2007; Adamska et al., 2016). The scholarship requires research in geographical areas where extant literature is scarce. Such research is likely to add another dimension to how strategic philanthropic behavior is enacted in non-Western environments and accelerate the elimination of barriers for its implementation. Only by broadening the scope of inquiry, can we reach clarity on what is strategic philanthropy and why companies choose to engage in it. Incorporating perspectives from post-communist countries can pluralize the discussion on strategic approach to philanthropy. This is necessary if strategic philanthropy is ever to become a concept that is not only useful at facilitating corporate philanthropy and its benefits but also at understanding what motivates companies in different locations must engage in this activity.

Further research should also focus on the influence of proposed factors on traditional corporate philanthropy in the Czech Republic and should compare results with this study. Such comparisons would further show whether the results of this study are arising from the philanthropic approach itself or the country where research is conducted. Further research could examine different models of strategic approaches to philanthropy and different potential drivers. Aspects indicating strategic approaches to philanthropy also include the alignment of a company's charitable gifts with "products and goals" or a company's mission (Saiia et al., 2003; Campbell and Slack, 2008). Other drivers mentioned in corporate philanthropy literature include the geographical level of operation (Useem, 1988; Saiia et al., 2003; Hanousek et al., 2010), company age (Wang 
and Qian, 2011; Marquis and Lee, 2013), and interests and values of managers (Useem, 1988; Buchholtz et al., 1999; Brammer et al., 2006; Marquis and Lee, 2013).

In practice, this research can conduce to the inclusion of the presence of strategic consideration into the assessment of companies' responsible behavior. In the Czech Republic, it is for example the "TOP responsible company" award. This would encourage companies to adopt strategic approach to philanthropy and further drive the positive impact of these actions.

\section{Limitations and Conclusion}

This study has several limitations. For strategic philanthropy, a more suitable proxy measure would be simultaneous impact measurement (Liket and Maas, 2016). However, the low percentage of companies measuring the impact of philanthropy on both business and society makes this variable inapplicable in terms of research. The companies in the sample reported on impact measurement but - when asked for more details (e.g. what type of indicators they use) - most stated they use their own (non-standardized) measurement instruments. This discrepancy makes it impossible to know whether they accurately measure the impact of their contributions. Furthermore, there is no registry of private companies engaged in corporate philanthropy in the Czech Republic, official data about philanthropic contributions is not available, and annual reports of many companies do not include suitable indicators that can serve as measures of philanthropic expenditures. The data regarding the amounts companies spend on philanthropic expenditures was obtained through a questionnaire survey, which is not as reliable a source of information as social responsibility reports that are common in developed capitalist countries.

This study aimed to contribute to a better understanding of the specifics of strategic approach to philanthropy in the Czech Republic by analyzing the identified factors that influence how companies engage in strategic philanthropy and philanthropic strategy. Moreover, this study specified the differences between strategic philanthropy and philanthropic strategy and the strategic motivations for philanthropy. The Czech companies engaged in corporate philanthropy participating in this study are at the beginning of the implementation of strategic processes associated with corporate philanthropy. They still have much to develop especially in terms of implementing strategic philanthropy. 


\section{References}

Anheier, H. and Winder, D. (2007). Innovations in strategic philanthropy: Lessons from Africa, Asia, Central and Eastern Europe, and Latin America. In: H. Anheier, A. Simmons, D. Winder (eds.), Innovations in Strategic Philanthropy: Local and Global Perspectives (First Edition ed., pp. 145). New York, NY: Springer.

Adamska, A., Dabrowski, T. and Grygiel-Tomaszewska, A. (2016). Socially Responsible Investment in Post-Communist and Developed European Countries. Revue d'études comparatives Est-Ouest, 3(3), 7-43. https://doi.org/10.4074/S0338059916003016.

Amato, L.H. and Amato, C.H. (2012). Retail Philanthropy: Firm Size, Industry, and Business Cycle. Journal of Business Ethics, 107(4), 435-448. https://doi.org/10.1007/s10551-011-1048-x.

Barraket, J. and Yousefpour, N. (2013). Evaluation and social impact measurement amongst small to medium social enterprises: Process, purpose and value. Australian Journal of Public Administration, 72(4), 447-458. https://doi.org/10.1111/1467-8500.12042.

Blasco, J.L. and King, A. (2017). KPMG Survey of Corporate Responsibility Reporting 2017. Obtained from: https://assets.kpmg/content/dam/kpmg/xx/pdf/2017/10/kpmg-survey-of-corporate-responsibility-reporting-2017.pdf (21 January 2019).

Block, E.S., Glavas, A., Mannor, M. J. and Erskine, L. (2017). Business for Good? An Investigation into the Strategies Firms Use to Maximize the Impact of Financial Corporate Philanthropy on Employee Attitudes. Journal of Business Ethics, 146(1), 167-183. https://doi.org/10.1007/s10551-015-2930-8.

Brammer, S. and Millington, A. (2005). Corporate Reputation and Philanthropy: An Empirical Analysis. Journal of Business Ethics, 61(1), 29-44. https://doi.org/10.1007/s10551-005-7443-4.

Brammer, S. and Millington, A. (2006). Firm size, organizational visibility and corporate philanthropy: An empirical analysis. Business Ethics: A European Review, 15(1), 6-18. https://doi.org/10.1111/j.1467-8608.2006.00424.x.

Brammer, S. and Millington, A. (2008). Does it pay to be different? An analysis of the relationship between corporate social and financial performance. Strategic Management Journal, 29(12), 1325-1343. https://doi.org/10.1002/smj.714.

Brammer, S., Millington, A. and Pavelin, S. (2006). Is philanthropy strategic? An analysis of the management of charitable giving in large UK companies. Business Ethics: A European Review, 15(3), 234-245. https://doi.org/10.1111/j.1467-8608.2006.00446.x.

Briš, P. and Brišová, H. (2013). The growing importance of the practical application of corporate social responsibility in the management of companies in the Czech Republic. Journal of Competitiveness, 5(2), 124-138. https://doi.org/10.7441/joc.2013.02.09.

Buchholtz, A.K., Amason, A.C. and Rutherford, M.A. (1999). Beyond Resources: The Mediating Effect of Top Management Discretion and Values on Corporate Philanthropy. Business \& Society, 38(2), 167-187. https://doi.org/10.1177/000765039903800203.

Campbell, D. and Slack, R. (2008). Corporate 'Philanthropy Strategy' and 'Strategic Philanthropy': Some Insights From Voluntary Disclosures in Annual Reports. Business \& Society, 47(2), 187-212. https://doi.org/10.1177/0007650306297941.

Chen, J.C. and Roberts, R.W. (2010). Toward a more coherent understanding of the organization-society relationship: A theoretical consideration for social and environmental accounting research. Journal of Business Ethics, 97(4), 651-665. https://doi.org/10.1007/s10551-010-0531-0.

Chojnacka, E. and Wiśniewska, J. (2016). Benefits of corporate social responsibility engagement in companies: the case of Poland. Journal of Management and Business Administration, 24(4), 25-48. https://doi.org/10.7206/jmba.ce.2450-7814.181. 
Costa, E. and Pesci, C. (2016). Social impact measurement: why do stakeholders matter? Sustainability Accounting, Management and Policy Journal, 7(1), 99-124. https://doi.org/10.1108/SAMPJ-12-2014-0092.

Donors Forum (2004). Jak jsme na tom s firemní filantropií v České republice? Výsledky výzkumu firemni filantropie. (How do we stand in the corporate philanthropy in the Czech Republic? Results of corporate philanthropy study). Obtained from: http://aa.ecn.cz/img_upload/65636e2e7a707261766f64616a737476/firemnifilantrop_vyzkum.doc (12 January 2020).

Emerson, J. (2003). The Blended Value Proposition: Integrating Social and Financial Returns. California Management Review, 45(4), 35-51. https://doi.org/10.2307/41166187.

European Commission (2015). User guide to the SME definition. Obtained from: https://op.europa. eu/en/publication-detail/-/publication/79c0ce87-f4dc-11e6-8a35-01aa75ed71a1 (10 January 2020).

Frič, P. (2001). Giving And Volunteering In The Czech Republic. Obtained from:https://www.researchgate.net/publication/40346192_darcovstvi_a_dobrovolnictvi_v_ceske_republice_vysledky_vyzkumu_nros_a_agnes (20 March 2020).

Gan, A. (2006). The Impact of Public Scrutiny on Corporate Philanthropy. Journal of Business Ethics, 69(3), 217-236. https://doi.org/10.1007/s10551-006-9087-4.

Gautier, A. and Pache, A.-C. (2015). Research on Corporate Philanthropy: A Review and Assessment. Journal of Business Ethics, 126(3), 343-369. https://doi.org/10.1007/s10551-013-1969-7.

Godfrey, P.C. (2005). The relationship between corporate philanthropy and shareholder wealth: A risk management perspective. Academy of Management Review, 30(4), 777-798. https://journals.aom.org/doi/10.5465/amr.2005.18378878.

Hanousek, J., Kočenda, E. and Svítková, K. (2010). Corporate philanthropy in the Czech and Slovak republics. Czech Journal of Economics and Finance (Finance a Uver), 60(2), 102-121.

Heike Bruch, F.W. (2005). The Keys to Rethinking Corporate Philanthropy. MIT Sloan Management Review, 47(1), 49-55.

Hess, D., Rogovsky, N. and Dunfee, T.W. (2002). The Next Wave of Corporate Community Involvement: Corporate Social Initiatives. California Management Review, 44(2), 110-125. https://doi.org/10.2307/41166125.

Hlavacek, P. and Bal-Domanska, B. (2016). Impact of foreign direct investment on economic growth in Central and Eastern European countries. Inzinerine Ekonomika-Engineering Economics, 27(3). https://dx.doi.org/10.5755/j01.ee.27.3.3914.

Kolibová, H. (2016). The Potential for Regional Corporate Philanthropy. Rocznik Administracji Publicznej, 2. https://doi.org/10.4467/24497800RAP.16.001.5094.

Keay, A. (2007). Tackling the Issue of the Corporate Objective: An Analysis of the United Kingdom's 'Enlightened Shareholder Value Approach. Sydney Law Review, 29(4), 577-612.

KPMG. (2017). Meet the heart of Europe. Investment in the Czech Republic. Obtained from: https:// assets.kpmg/content/dam/kpmg/cz/pdf/KPMG_Investment-in-Czech-Republic.pdf (21 January 2019).

Liket, K. and Maas, K. (2016). Strategic Philanthropy: Corporate Measurement of Philanthropic Impacts as a Requirement for a 'Happy Marriage' of Business and Society. Business \& Society, 55(6), 889-921. https://doi.org/10.1177/0007650314565356.

Maas, K. and Liket, K. (2011). Talk the Walk: Measuring the Impact of Strategic Philanthropy. Journal of Business Ethics, 100(3), 445-464. https://doi.org/10.1007/s10551-010-0690-z.

Marquis, C. and Lee, M. (2013). Who Is Governing Whom? Executives, Governance, and the Structure of Generosity in Large U.S. Firms. Strategic Management Journal, 34, 483-497. https://doi.org/10.1002/smj.2028. 
Marx, J.D. (1996). Strategic philanthropy: an opportunity for partnership between corporations and health/human service agencies. Administration in Social Work, 20(3), 57-73. https://doi.org/10.1300/J147v20n03_04.

Mohan-Neill, S.I. (1995). The influence of firm's age and size on its environmental scanning activities. Journal of Small Business Management, 33(4), 10.

O’Brien, R.B. (2007). Caution Regarding Rules of Thumb for Variance Inflation Factors, Quality and Quantity, 41(5), 673-690. https://doi.org/10.1007/s11135-006-9018-6.

Porter, M.E. and Kramer, M.R. (2006). Strategy and Society: The Link Between Competitive Advantage and Corporate Social Responsibility. Obtained from: https://hbr.org/2006/12/strategy-and-society-the-link-between-competitive-advantage-and-corporate-social-responsibility (12 March 2018).

Post, J.E. and Waddock, S.A. (1995). Strategic philanthropy and partnerships for economic progress, philanthropy and economic development. In: R.F. America (ed.), Philanthropy and Economic Development (pp. 167-191). Westport, CT: Greenwood Press.

Saiia, D.H., Carroll, A.B. and Buchholtz, A.K. (2003). Philanthropy as Strategy: When Corporate Charity 'Begins at Home'. Business \& Society, 42(2), 169-201. https://doi.org/10.1177/0007650303042002002.

Seifert, B., Morris, S.A. and Bartkus, B.R. (2003). Comparing Big Givers and Small Givers: Financial Correlates of Corporate Philanthropy. Journal of Business Ethics, 45(3), 195-211. https://doi.org/10.1023/A:1024199411807.

Sundaram, A.K. and Inkpen, A.C. (2004). Stakeholder Theory and "The Corporate Objective Revisited": A Reply. Organization Science, 15(3), 370-371. https://doi.org/10.1287/orsc.1040.0067.

Štastná, J., Fraňková, E. and Stránský, J. (2011). Závěrečná zpráva o činnosti 5. pracovní skupiny „Mapování způsobů měření dopadů sociálního podnikání. Vyhodnocení pilotního ověření metodiky SROI v sociální firmě Modrý domeček, Řevnice. Obtained from: http://server.universium.cz/publikace/16a_zaverecna_zprava_PS_mereni.pdf (20 March 2017).

Useem, M. (1988). Market and Institutional Factors in Corporate Contributions. California Management Review, 30(2), 77-88. https://doi.org/10.2307/41166548.

Valor, C. (2006). Why do managers give? Applying pro-social behavior theory to understand firm giving. International Review on Public and Non Profit Marketing, 3(1), 17-28. https://doi.org/10.1007/BF02893282.

Válová, A. and Formánková, S. (2014). Corporate philanthropy in the Czech Republic. Procedia Economics and Finance, 12, 725-732. https://doi.org/10.1016/S2212-5671(14)00399-2.

Wang, H. and Qian, C. (2011). Corporate philanthropy and corporate financial performance: The roles of stakeholder response and political access. Academy of Management Journal, 54(6), 1159-1181. http://dx.doi.org/10.5465/amj.2009.0548.

Wójcik, P. (2016). How creating shared value differs from corporate social responsibility. Journal of Management and Business Administration, 24(2), 32-55.

https://doi.org/10.7206/jmba.ce.2450-7814.168.

Wójcik, P. (2018). The business case for corporate social responsibility: A literature overview and integrative framework. Journal of Management and Business Administration. Central Europe, 26(1), 121-148, https://doi.org/0.7206/jmba.ce.2450-7814.222. 


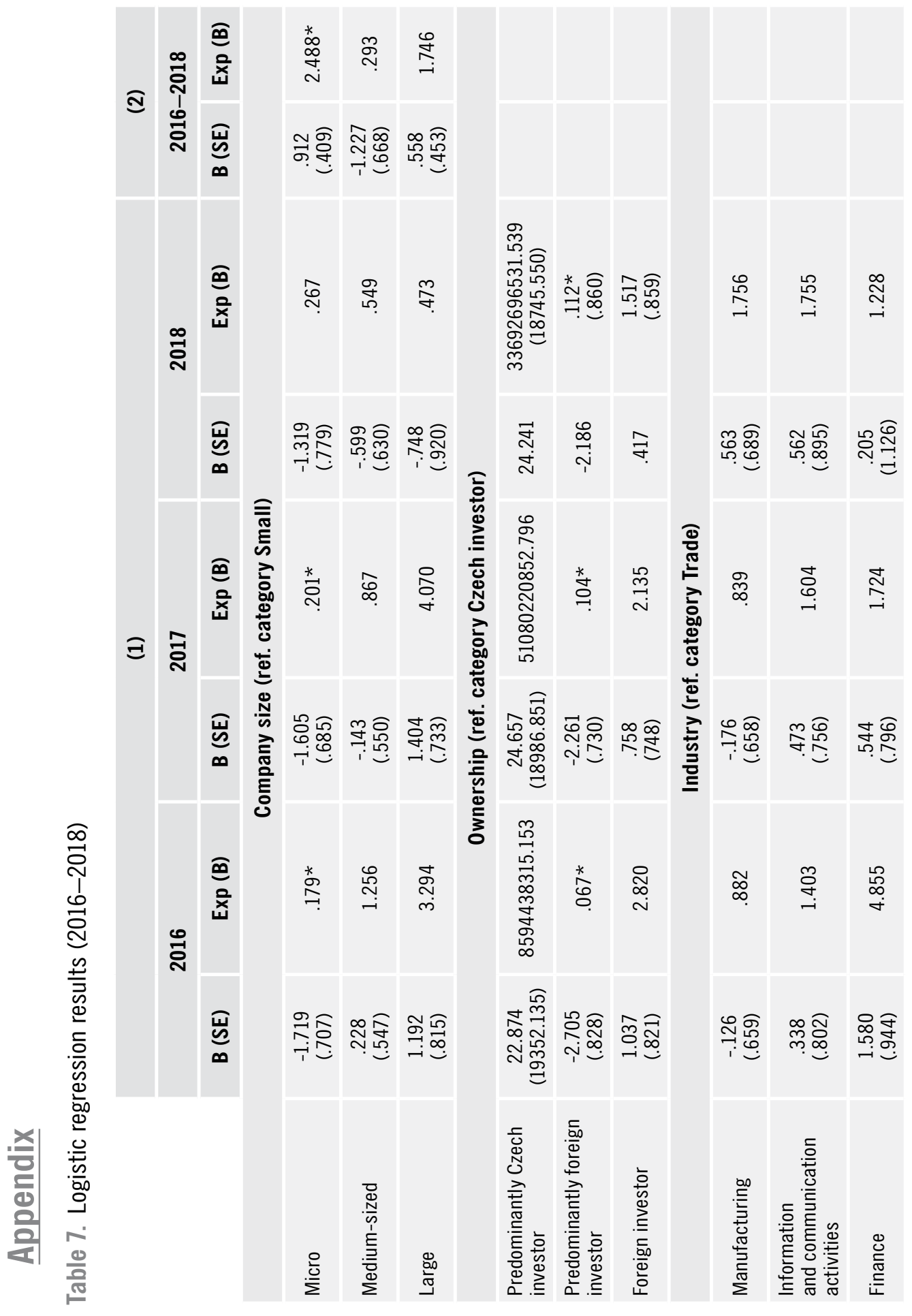




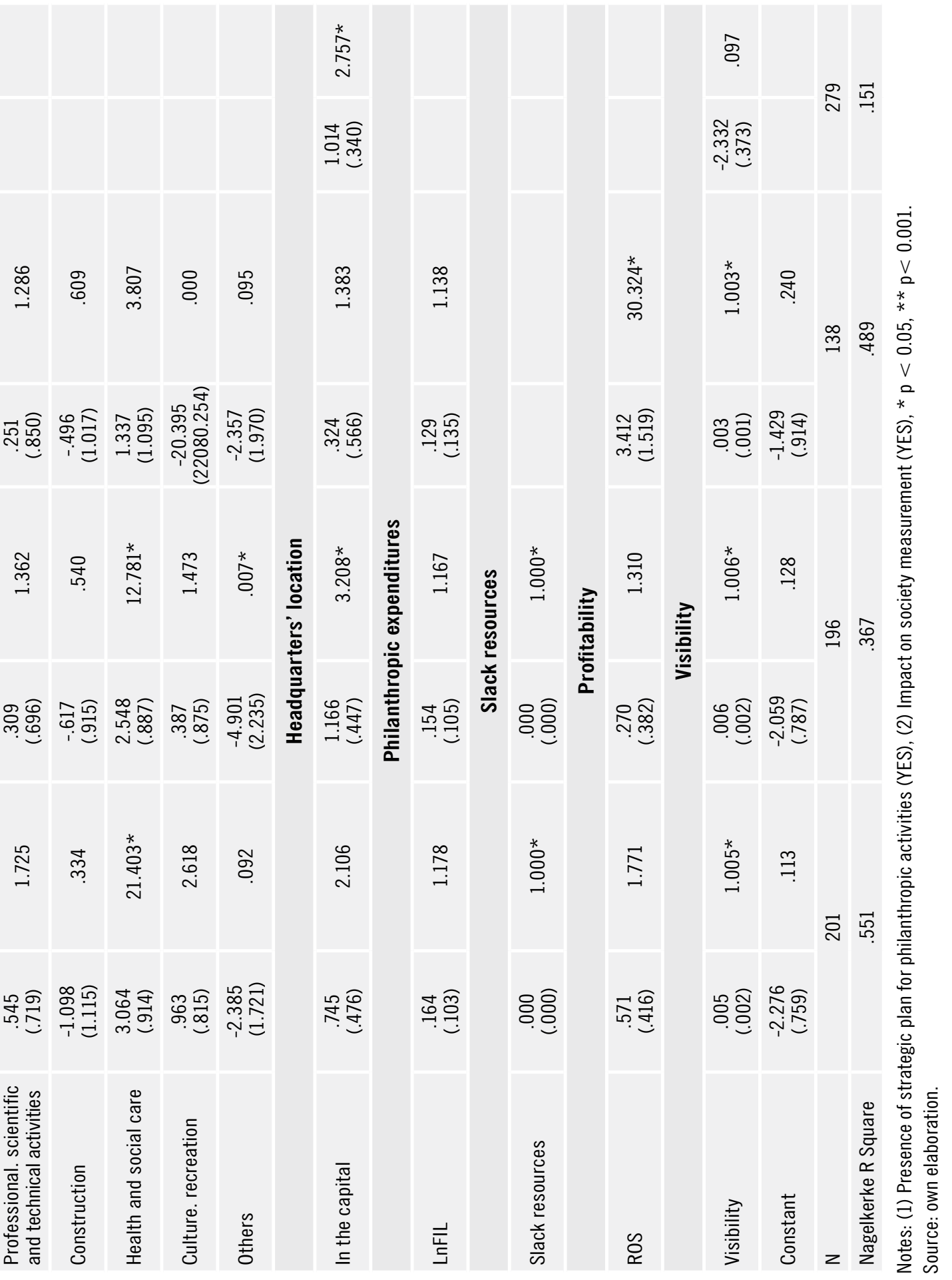

